\title{
Helix lucorum Linnaeus 1758 (Mollusca: Gastropoda: Helicidae) elterjedése, héjalaktana Budapest XI. és XII. (Hegyvidék) kerületében
}

\author{
DOMOKOS TAMÁS ${ }^{1}$ és PÁLL-GERGELY BARNA²
}

\author{
${ }^{1} \mathrm{H}-1124$ Budapest, Bürök utca 24-26., e-mail: tamasdomokos@freemail.hu \\ 2Magyar Tudományos Akadémia Növényvédelmi Kutatóintézet, H-1022 Budapest, Herman Ottó út 15. \\ e-mail: pallgergely2@gmail.com
}

\begin{abstract}
Domokos, T. \& PÁlL-Gergely, B.: Distribution and shell morphology of Helix lucorum in Districts XI and XII, Budapest, Hungary.

Abstract: According to social media network Helix lucorum prefers hilly country. We present morphometric results for five populations of the Helix lucorum from lowland $\left(\mathrm{XI}^{\text {th }}\right.$.) and hilly $(\mathrm{XII})$ country. It has found the arithmetic mean of Helix lucorum height $(\mathrm{H})$ and width $(\mathrm{W})$ expand, but globosity approximately unchanged by height above see level.
\end{abstract}

Keywords: abundance, biometrics, globosity $(\mathrm{W} / \mathrm{H})$, frequency distribution curve, shell morphology

\section{Bevezetés}

1986-ban Nagy Lóránt Szófia környékéröl, a bulgáriai Vitosából kaposvári kertjébe - kísérleti céllal néhány példány fehérsávos éticsigát (Helix lucorum) telepített (VARGA 1995). Ez a faj akkor még igencsak kuriózumnak számított hazánkban, és sokan nem is hittek abban, hogy a föleg mediterrán területekre jellemző faj hazánkban is megveti majd a talpát.

Az elmúlt 33 év alatt jelentősen megváltozott az általunk bemutatásra kerülő faj inváziójának, migrációjának a megítélése (VARGA et al. 2010, BODOR 2014, Domokos 2005, 2014, PÁlL-Gergely et al. 2019). PállGergely Barna és munkatársai egy közösségi média weboldalon (Facebook) végzett adatgyűjtést Budapesten a cirádás éticsigával (Cornu aspersum) párhuzamosan. A felmérés konklúziói eklatánsan bizonyítják mindkét faj térnyerését. Ez a munka Budapest 44 pontjáról közli a Helix lucorum előfordulását.

A nem várt mennyiségű faunisztikai adat többek között a következő kérdéseket veti fel az olvasóban. Mivel magyarázható a Helix lucorum sikeres adaptációja? Miért csekély az ismert vidéki populációk száma? Egyes előfordulási helyein mekkora abundancia értékek jellemzik? Mennyire változatos a vizsgált faj héjmorfológiája? Hibridizál-e a honos éti csigánkkal (Helix pomatia Linnaeus, 1758)?

A korábban citált irodalmak alapján az első két kérdésre már születtek válaszok. Ezek ökológiai és etológiai alapon magyarázták a Helix lucorum sikeres migrációját. Egyrészt a klíma mediterránosodása, a nagyvárosok amúgy is magasabb átlaghőmérséklete, másrészt az évi dormanciájának éti csigához viszonyított csekélyebb ideje eredményezi a sikeres „konkvisztádorkodást”.

A fővárost hatalmas, migrációt megkönnyítő élőhely sokasága, valamint nagy diverzitású és dinamizmusú kertkultúrák jellemzik. Az előbb soroltak kevésbé jellemzőek a vidékre, ráadásul az ottani adatok nem szisztematikus felmérés, hanem ad hoc megfigyelések, észrevételek, betelepítések szüleményei (a facebookos felmérés kifejezetten a budapestieket célozta).

A válasz nélkül maradt kérdésekre (abundancia, héjmorfológia, hibridizáció) jelen írásunkban szeretnénk feleletet adni.

\section{Anyag és módszer}

\section{Gyüjtőhelyek, minták}

Amint az 1. ábrából is kiderül, a Helix lucorum Budát preferálja, talán történeti okokból, ott terjedt el a behurcolt faj. Buda következő kerületeiből jöttek a közösségi médiahálózatos visszajelzések: II., III., XI., XII. Ezek közül - a találatok száma alapján - a XII. kerület (Hegyvidék) látszott alkalmasnak arra, hogy olyan biotópokat keressünk, amelyekben előforduló populációk sokasága/egyedszáma alkalmas a megfelelő morfológiai karakterisztikák nyerésére.

A XII. kerület 2018-as és 2019-es bejárása során a következö helyeken sikerült a fehérsávos éticsiga jelenlétét megállapítani: Apor $\mathrm{V}$. tér, Böszörményi u., Bürök u., Diana u., Farkasréti temető, Fodor u., Jagelló út, Mártonhegyi út, Mártonlaki u., Nárcisz u., Németvölgyi lépcső, Ormódi u., Stromfeld A. u., Szépkilátás u., Szendi árok, Szendi u., Tállya u., Tamási Á. u., Zólyomi lépcső.

$A z$ itt sorolt előfordulási helyek közül - tekintettel az egyedszámokra - egyeléses vizsgálatra a következő biotópokat találtuk alkalmasnak:

- Apor Vilmos tér, a Jagelló út és a Németvölgyi út megközelítően a Vas Gereben utcáig terjedő, közel 500 m-es hosszú és, D-ies DK-ies expozíciójú völgyszakasza ( $\left.75000 \mathrm{~m}^{2}\right)$. Az egyre meredekebben lejtő 5-20 $m$ széles löszgyepet itt-ott fák és bokrok tarkázzák, így lehetősége van a fehérsávos éticsigának a számára szárazabb időszakban napozó-, illetve menedékhelyet találnia. Búvóhelynek - tapasztalatunk szerint - elsősorban az ördögcérna bokrokat preferálják. A gyűjtés időpontja: 2019. 06. 22. A gyüjtött holt példányok száma: 33. AMSL (tengerszint feletti magasság): $173 \mathrm{~m}$.

- Bürök u. 34-36. A Bürök u. és a Németvölgyi lépcső felé eső betonkerítés zugában, egy magas épület közelében található biotóp. A DK-felé lejtő elzárt park megközelítően $50 \mathrm{~m}^{2}$-es bokros részét a kerítéssel egyetemben vadszőlő borította be. Ezt a biotópot találtuk a legfedettebbnek és legárnyékoltabbnak. 
A kerítés megóvása céljából a bokrost 2019-ben fokozatosan kiirtották, és ezzel lehetővé tették a Helix lucorum csigaegyüttes alapos tanulmányozását, az élők áttelepítését, a holtak begyűjtését (Élő alatt az E1 és E2 létállapotú példányokat értjük - DOMOKOS 1995). A kertészeti munkálatokhoz igazodó gyűjtések időpontjai: 2019. 09. 10.,11., 16., 20. A gyűjtött holt, illetve élő példányok száma: 52 , illetve 88 . Száraz-esős időszak váltakozása esetén tapasztalható volt a Helix lucorum Farkasréti temető irányába (20-30 m távolságra) történő migrációja, amely különösen bokros rész irtását követően volt szembetűnő. A csigáknak két kerítést kellett megmászniuk ahhoz, hogy a temető bokros részein búvóhelyet találjanak. A mérést követően a 88 élő példány - humanitárius indíttatás érzésével hajtva - egy közeli bokrosba került áttelepítésre. Abundancia (példány $/ \mathrm{m}^{2}$ ) vizsgálatára ebben a Bürök utcai habitatban került sor. ASML: $210 \mathrm{~m}$.

- Mártonhegyi út 15/F melletti beépítetlen, megközelítően $350 \mathrm{~m}^{2}$-es, építési törmelékkupacos erdőrész (juhar, kőris, bodza, fagyal), amelyet egyik oldalán magas kerítés zár el a beépített területtől. A gyüjtés időpontja: 2019. 10. 13. A holtfa habitatból 59 holt, a vakolt magaskerítésről pedig 17 E2-es létállapotú adult egyed került vizsgálatra. (A kerítésen talált juvenilis példányok száma 51-re rúgott!) Esős időszak után (2019. 11. 11.) csupán a falon elszórva található ürülék jelezte vizsgált fajunk egykori helyfoglalását. AMSL: $351 \mathrm{~m}$.

- Mártonhegyi út 11/D melletti beépítetlen, sok holtfával tarkított, megközelítően $600 \mathrm{~m}^{2}$-es erdőrész (juhar, kőris, orgona, som). A gyűjtés időpontja: 2019. 10. 10. A gyűjtött holt példányok száma: 50 . Esős időszak után (2011. 10. 10.) az erdőtől D-re található villák kerítésén, megközelítően 50 m hosszan, 29 db E2-es létállapotú adult és juvenilis Helix lucorum példányt lehetett megszámolni. Ezek - ideánk szerint - az erdőfoltot egykoron elhagyó egyedek lehettek. ASML: 367 m.

- Az előbbi négy hegyvidéki lelőhelyet megtoldottuk egy Bocskai (75. sz.) és Daróci út (30. sz.) találkozásánál fekvő XI. kerületi kicsinyke, 7,5 $\mathrm{m}^{2}$-es téglalap alakú parkrésszel. A kis parkot nemrég „rendszabályozták”, azaz a tiszafák és fagyal bokrok egy részét kiirtották, visszavágták és ezzel számunkra 14 darab mérésre alkalmas holt Helix lucorum begyűjtését tették lehetővé. Mivel a vizsgált terület a Bocskai és a Daróci út találkozása szögletében, valamint egy körforgalom közelében fekszik, ezért nagyon kitett a felmelegedésnek és a kiszáradásnak. Feltételezésünk szerint ez a kisméretű biotóp a hegyvidékieknél szélsőségesebb mikroklímával rendelkezik. A gyüjtés időpontja: 2019. 08. 01. A gyűjtött holt példányok száma csupán 14. A Daróci utcában, a kis térttől megközelítően 350 m-re egy épület falán magányos fehérsávos éticsigát találtunk. Az itteni lelet azt sugallja, hogy vizsgált fajunk a talpán hihetetlen távolságokra el tud jutni. AMSL: $111 \mathrm{~m}$.

Amintazelőbbi felsorolásból kitünik, a hegyvidéki gyűjtőhelyek tengerszint feletti magassága kisebb-nagyobb ugrásokkal növekszik. Az alföldi minta (Bocskai-Daróci út) a legalacsonyabb hegyvidéki mintánál csupán 63 m-rel van alacsonyabban. A Bocskai-Daróci utcai és a Mártonhegyi út 11/D minta ASML különbsége már jelentős: $256 \mathrm{~m}$. Ez azt jelenti, hogy az átlagos hőmérsékleti gradiens alapján megközelítően $2{ }^{\circ} \mathrm{C}$-al alacsonyabb a Márton-hegyen a hőmérséklet, mint az alföldi mintánál. Természetesen az egyes gyűjtőhelyek egyéb éghajlati tényezői (Nap sugárzása, felszín albedója, domborzati adottságok, növényborítottság, emberi tényezők sokasága stb.) is befolyásolják az általunk vizsgált fehérsávos éticsigák életterének, mikroterének klímáját. Közismert, hogy a mikroterek éghajlati elemei közötti eltérés, a kicsi kiterjedésük ellenére, sokkal nagyobb is lehet, mint az igen nagy távolságra lévő nagy makrotereké.

A héjalaktani vizsgálatunkat követően tanulmányozni fogjuk a házak átlagszélességének és átlagmagasságának tengerszint feletti magasságtól való függését.

\section{Abundancia; héjmorfológiai mérés, feldolgozás}

Terepi adottságok miatt a Bürök utcai habitat volt alkalmas a precízebb abundancia érték meghatározására. Ehhez feltételeztük, hogy a Helix lucorum klimax

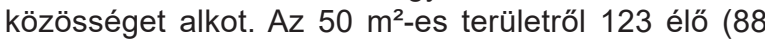
adult és 35 juvenilis) és 52 holt adult példány került elő. Ergo, az az összes élő példány esetén az abundancia 2,4 , adultak esetében pedig $1,7 \mathrm{db} / \mathrm{m}^{2}$.

A bokros biotópban talált 88 E1/E2 létállapotú adult Helix lucorum mellett csupán 8 hasonló létállapotú Helix pomatia került elö, ami csupán csak 0,16-os abundanciát jelent.

A héjmorfológiai vizsgálatokhoz kifejlett, kihajlott szegélyű szájadékkal rendelkező példányokat használtunk. Mivel a szájadék szegélyének kihajlása egyedenként igen különböző irányú és nagyságú lehet (1-2 $\mathrm{mm}$ ), az azonos kritériumok alapján történő mérésről kénytelenek voltunk lemondani.

A ház szélességét $(W)$ és magasságát $(H)$ tolómérővel mértük $\pm 0,2 \mathrm{~mm}$ illetve $\pm 0,3 \mathrm{~mm}(\sim 1 \%)$ pontossággal.

A szélesség/átmérő mérése problémamentesen oldható meg, hiszen a szájadékával a tolómérő két pofája közé - felfelé néző szájjal - könnyen befogható a ház szájadék szegélye és a vele szemben fekvő utolsó kanyarulatrésze. A tolóka finom mozgatásával elérhető, hogy a szegély ne sérüljön meg.(A ház olyan finoman befogható, hogy könnyen, kiesés nélkül elfordulhat a pofák között. A még mészszegény szegély a rugalmassága, az elmeszesedett szegély pedig a törékenysége miatt okozhat problémát.)

A magasság mérése már problematikusabb feladat. Itt a házat a tolómérő két pofája közé úgy kell beilleszteni, hogy a szájadékával magunk felé fordított ház csúcsán és a fedett vagy részben fedett köldökén átfutó virtuális tengely merőlegesen álljon a pofákra. A szélesség és a magasság értékpárok meghatározását követően kiszámítottuk a ház gömbölyüségét jellemző (W/H) értéket is. Tökéletesen „gömbölyü” a ház $W / H=1$ esetén. Ha a hányados értéke 1-nél kisebb, akkor húzott, ha 1-nél nagyobb, akkor nyomott házformáról beszélünk. 
ELTERJEDÉSE, HÉJALAKTANA

1. táblázat. A Helix lucorum ház szélesség (W) értékeihez tartozó geográfiai, statisztikai adatai a különböző gyüjtőhelyeken és időpontokban.

\begin{tabular}{|c|c|c|c|c|c|}
\hline $\begin{array}{c}\text { gyüjtőhelyek/ } \\
\text { sampling sites }\end{array}$ & $\begin{array}{c}\text { Bocskai- } \\
\text { Daróci }\end{array}$ & $\begin{array}{c}\text { Apor Vilmos } \\
\text { tér }\end{array}$ & Bürök u. 34-36 & $\begin{array}{c}\text { Mártonhegyi út } \\
11 / F\end{array}$ & $\begin{array}{c}\text { Mártonhegyi } \\
\text { út 11/D }\end{array}$ \\
\hline tszfm/AMSL (m) & $\sim 111$ & $\sim 173$ & $\sim 210$ & $\sim 351$ & $\sim 367$ \\
\hline kitettség/exposure & $\mathrm{D} / \mathrm{S}$ & $\mathrm{D} / \mathrm{S}$ & $\mathrm{DK} / \mathrm{SE}$ & \multicolumn{2}{|c|}{$\mathrm{DNy/SW}$} \\
\hline dátum/date & 2019.08 .01$. & 2019.6 .22$. & $2019.09 .10 ., 11 ., 16 ., 20$. & 2019.10 .13$. & 2019.10 .10$. \\
\hline $\begin{array}{c}\text { példányszám/ } \\
\text { number of case } \\
\text { holt/élö } \\
\text { dead/living }\end{array}$ & $14 / 0$ & $33 / 0$ & $52 / 88$ & $59 / 17$ & 50 \\
\hline $\begin{array}{c}\text { min. érték/value } \\
\text { (mm) }\end{array}$ & 31,7 & 36 & $36,8 / 36,1$ & $35,5 / 37,6$ & 36,8 \\
\hline $\begin{array}{c}\text { max. érték/value } \\
\text { (mm) }\end{array}$ & 41 & 43,6 & $50,6 / 46,1$ & $44,4 / 44,3$ & 44,6 \\
\hline $\begin{array}{c}\text { terjedelem/ range } \\
\text { of measuring }\end{array}$ & 9,3 & 7,6 & $13,8 / 10$ & $8,9 / 6,7$ & 7,8 \\
\hline $\begin{array}{c}\text { átlag/arithmetic } \\
\text { mean (mm) }\end{array}$ & 37,16 & 38,77 & $41,40 / 40,81$ & $40,15 / 39,96$ & 40,85 \\
\hline $\begin{array}{c}\text { módusz/mode } \\
\text { (mm) }\end{array}$ & $37-39$ & $37-39$ & $39-41 / 41-43$ & $41-43 / 37-39$ & $39-41$ \\
\hline $\begin{array}{c}\text { szórás/standard } \\
\text { deviation }\end{array}$ & 2,63 & 1,92 & $2,45 / 1,80$ & $2,21 / 1,90$ & 2,26 \\
\hline
\end{tabular}

2. táblázat. A Helix lucorum ház magasság $(H)$ értékeihez tartozó geográfiai, statisztikai adatai a különböző gyüjtőhelyeken és időpontokban.

\begin{tabular}{|c|c|c|c|c|c|}
\hline $\begin{array}{c}\text { gyüjtöhelyek/ } \\
\text { sampling sites }\end{array}$ & $\begin{array}{c}\text { Bocskai- } \\
\text { Daróci út }\end{array}$ & $\begin{array}{c}\text { Apor Vilmos } \\
\text { tér }\end{array}$ & Bürök u. 34-36 & $\begin{array}{c}\text { Mártonhegyi } \\
\text { út 15/F }\end{array}$ & $\begin{array}{c}\text { Mártonhegyi út } \\
\text { 11/D }\end{array}$ \\
\hline tszfm/AMSL (m) & $\sim 111$ & $\sim 173$ & $\sim 210$ & $\sim 351$ & $\sim 367$ \\
\hline kitettség/exposure & $\mathrm{D} / \mathrm{S}$ & $\mathrm{D} / \mathrm{S}$ & $\mathrm{DK} / \mathrm{SE}$ & \multicolumn{2}{|c|}{$\mathrm{DNy} / \mathrm{SW}$} \\
\hline dátum/date & 2019.08 .01$. & 2019.6 .22$. & $2019.09 .10 ., 11 ., 16 ., 20$. & 2019.10 .13$. & 2019.10 .10$. \\
\hline $\begin{array}{c}\text { példányszám/ } \\
\text { number of case } \\
\text { holt/élő } \\
\text { dead/living }\end{array}$ & $14 / 0$ & $33 / 0$ & $52 / 88$ & $59 / 17$ & 50 \\
\hline $\begin{array}{c}\text { min. érték/value } \\
\text { (mm) }\end{array}$ & 26,9 & 30 & $29,9 / 30,6$ & $29,1 / 30,2$ & 29,9 \\
\hline $\begin{array}{c}\text { max. érték/value } \\
\text { (mm) }\end{array}$ & 36 & 41,1 & $39,9 / 40,2$ & $38,0 / 38,5$ & 38 \\
\hline $\begin{array}{c}\text { terjedelem/ range } \\
\text { of measuring }\end{array}$ & 9,1 & 11,1 & $10,0 / 9,6$ & $9,1 / 8,3$ & 8,1 \\
\hline $\begin{array}{c}\text { átlag/arithmetic } \\
\text { mean (mm) }\end{array}$ & 31,2 & 33,1 & $34,38 / 34,17$ & $34,37 / 33,96$ & 34,07 \\
\hline $\begin{array}{c}\text { módusz/mode } \\
\text { (mm) }\end{array}$ & $29-31$ & $31-33$ & $33-37 / 33-35$ & $35-37 / 33-35$ & $31-33$ \\
\hline $\begin{array}{c}\text { szórás/standard } \\
\text { deviation }\end{array}$ & 2,51 & 2,46 & $1,96 / 2,03$ & $2,00 / 1,90$ & 2,19 \\
\hline
\end{tabular}


3. táblázat. A Helix lucorum ház „gömbölyüség” (W/H) értékeihez tartozó geográfiai, statisztikai adatai a különböző gyüjtőhelyeken és időpontokban.

\begin{tabular}{|c|c|c|c|c|c|}
\hline $\begin{array}{l}\text { gyüjtőhelyek/ } \\
\text { sampling sites }\end{array}$ & $\begin{array}{l}\text { Bocskai- } \\
\text { Daróci út }\end{array}$ & $\begin{array}{c}\text { Apor Vilmos } \\
\text { tér }\end{array}$ & Bürök u. 34-36 & $\begin{array}{l}\text { Mártonhegyi } \\
\text { út 15/F }\end{array}$ & $\begin{array}{c}\text { Mártonhegyi út } \\
11 / D\end{array}$ \\
\hline tszfm/HASL (m) & $\sim 111$ & $\sim 173$ & $\sim 210$ & $\sim 351$ & $\sim 367$ \\
\hline kitettség/exposure & $\mathrm{D} / \mathrm{S}$ & $\mathrm{D} / \mathrm{S}$ & DK/SE & \multicolumn{2}{|c|}{ DNy/SW } \\
\hline dátum/date & 2019.08.01. & 2019.6.22. & 2019.09.10.,11.,16.,20. & 2019.10 .13 & 2019.10.10. \\
\hline $\begin{array}{c}\text { példányszám/ } \\
\text { number of case } \\
\text { holt/élő } \\
\text { dead/living }\end{array}$ & $14 / 0$ & $33 / 0$ & $52 / 88$ & $59 / 17$ & 50 \\
\hline $\begin{array}{c}\text { min. érték/value } \\
(\mathrm{mm})\end{array}$ & 1,11 & 1,02 & $1,08 / 1,04$ & 1,07 & 1,09 \\
\hline $\begin{array}{l}\text { max. érték/value } \\
(\mathrm{mm})\end{array}$ & 1,25 & 1,31 & $1,37 / 1,31$ & 1,26 & 1,39 \\
\hline $\begin{array}{l}\text { terjedelem/ range } \\
\text { of measuring }\end{array}$ & 0,14 & 0,29 & $0,29 / 0,27$ & 0,19 & 0,3 \\
\hline $\begin{array}{l}\text { átlag/arithmetic } \\
\text { mean }(\mathrm{mm})\end{array}$ & 1,18 & 1,16 & $1,20 / 1,19$ & 1,16 & 1,19 \\
\hline $\begin{array}{l}\text { módusz/mode } \\
\text { (mm) }\end{array}$ & $1,15-1,20$ & $1,15-1,20$ & $1,15-1,20 / 1,15-1,20$ & $1,15-1,20$ & $1,15-1,20$ \\
\hline $\begin{array}{c}\text { szórás/standard } \\
\text { deviation }\end{array}$ & 0,04 & 0,06 & $0,06 / 0,06$ & 0,04 & 0,05 \\
\hline
\end{tabular}

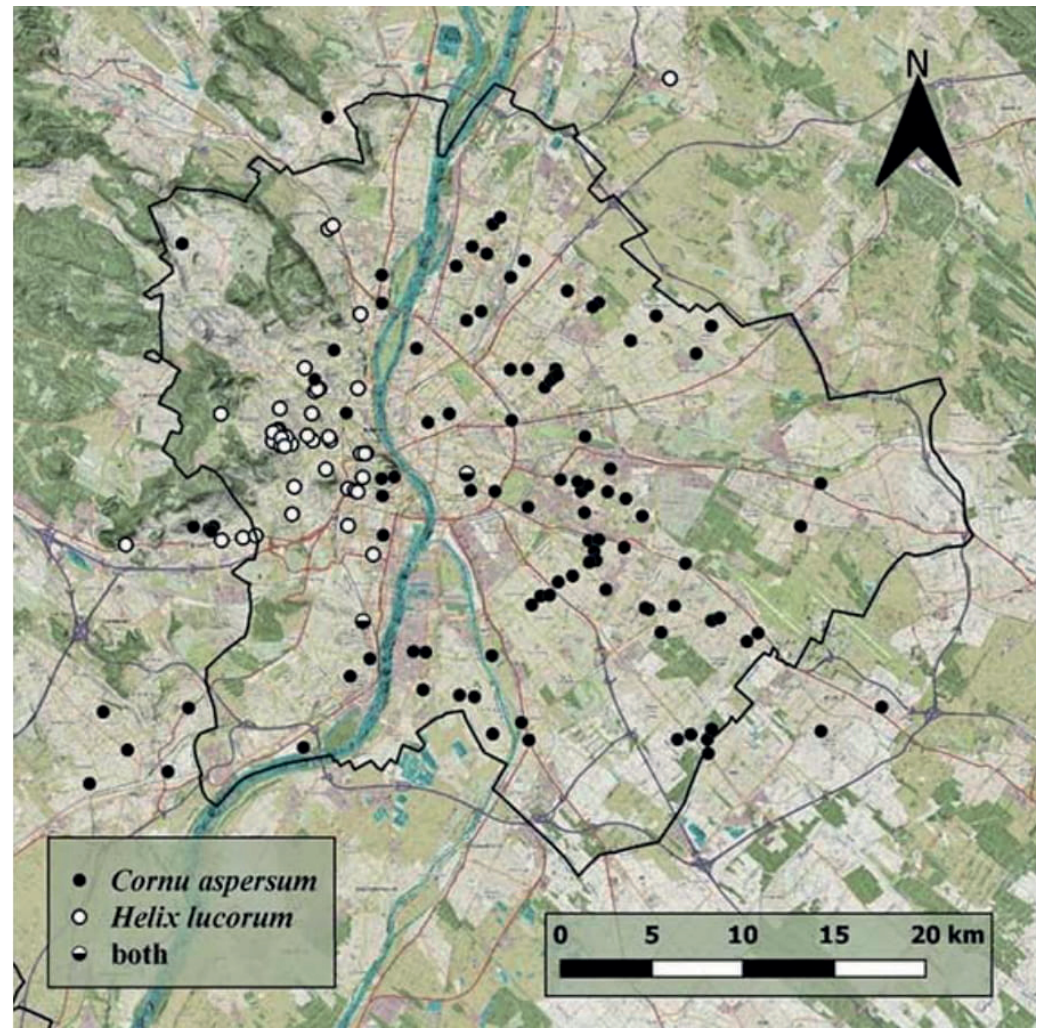

1. ábra. Cornu aspersum és Helix lucorum elöfordulása Budapesten és környékén (PÁLL-GERGELY et al. 2019). 


\section{Eredmények és következtetések}

Az összegyűjtött adatokat (gyűjtőhely megnevezése, tengerszint feletti magasság, kitettség, gyűjtés időpontja), statisztikai jellemzőket (példányszám, maximum és minimum érték, mérés terjedelme, átlag, módusz és szórás) héjmorfológiai jellemzők szerint külön-külön táblázatba foglaltuk (1., 2., 3. táblázat). A táblázatokban található tengerszint feletti magasság értékeket (AMSL) a Google Maps Find Altitude-Draft Logic segítségével határoztuk meg. Az adatok táblázatos bemutatása mellet a $W, H$ és $H / W$ gyakorisági eloszlását, grafikus interpretációját is bemutatjuk külön holt és élő állapot vonatkozásában (2.-7. ábra). Az eloszlásnál az osztályközöket a szórásnak megfelelően választottuk meg (1., 2., 3. táblázat). Ennek megfelelően $\mathrm{W}$ és $\mathrm{H}$ esetében $2 \mathrm{~mm}$-es, hányadosuknál pedig 0,05-os osztályközt alkalmaztunk.

Amint az a táblázatokból kitünik, a vizsgált habitátokban a ház szélességének, illetve magasságának legkisebb-legnagyobb értékpárja: 31,7-50,6 illetve 26,9-41,1 mm. Mindkét esetben a minimum értékek a Bocskai és Daróci úti, a maximum értékek pedig a Bürök utcai és az Apor Vilmos tér-Jagelló út-Németvölgyi úti gyűjtőhelyhez kötődnek. A2. és 3. ábra tanulmányozásából az is kiderül, hogy a Bocskai és Daróci úti, valamint az Apor Vilmos tér-Jagelló út-Németvölgyi úti biotóp Helix lucorum adaptív zónája szűkebb, mint a többieké, amit a héjjellemzők kisebb értékei is alátámasztanak.

Itt szeretnénk megjegyezni, hogy a Wikipédia szélességre/átméröre 45-55, magasságra 30-60 mm értékközt ad meg, a World of Molluscs szintén 30 és $60 \mathrm{~mm}$ közé teszi a szélesség nagyságát, WELTERSCHULTES 2012 pedig a szélességre 41-55 $(\rightarrow 60)$, a magasságra pedig 40-50 mm értékközt ad meg. Ezek tükrében az általunk mért szélesség és magasság minimumok kisebbek.

Varga András már citált munkájában (VARGA 1995) három kaposvári Helix lucorum példány magasság $\times$ szélesség értékét közli: $34 \times 40,34,5 \times 39,5,34 \times 40,5$. Vizsgálataink alapján kijelenthetjük, hogy a kaposvári értékek jól megközelítik a Budapesten mért leggyakoribb értékeket.

A házak szélesség és magasság értékeinek gyüjtőhelyenkénti eloszlása (2., 3. és 4. ábra) elég kaotikus képet mutat. Csupán a Bürök utcai minta eloszlását lehet egy kis jó szándékkal normálisnak nevezni, a többieket ferde és csúcsos eloszlás kategóriájába lehet besorolni. Mivel a Bürök utcai és a Mártonhegyi úti minták példányszámai megközelítően azonosak ( 50), az eloszlásban mutatkozó különbségeket nem a példányszám, hanem a kevert populációk számlájára lehet írni. A kevert populációk észlelése természetese összefügg a gyűjtőterület nagyságával és az ott tapasztalható abundanciával is. Gyűjtőhelyeink sorrendjében a mintahelyek nagysága a következő volt: 7,5-75 000-50-350-600 m². Ezek közül az 50 m²-es $^{2}$ nagy abundanciájú mintahelyen tapasztalunk megközelítően normális eloszlást. A többiek vagy a terület csekélységéből adódó $\left(7,5 \mathrm{~m}^{2}\right)$ nem elégséges minta- szám, vagy a terület túlzott nagyságából adódó kevert populációk miatt mutatnak itt-ott sztochasztikusság irányába mutató ferde vagy csúcsos eloszlást.

A gömbölyűség (W/H) gyűjtőhelyenkénti eloszlása - az eddig vizsgált szélesség és magasság eloszlásokhoz képest - meglepő képet mutat (4. ábra). Ugyanis itt közelítenek legjobban az eloszlási görbék egymáshoz és a normál eloszláshoz. A leggyakoribb értékek minden esetben 1,15-1,20 osztályközbe esnek. $\mathrm{Az}$ átlagok a különböző gyűjtőhelyeken csupán néhány \% -ban térnek el egymástól, és minden esetben a módusz osztályközbe esnek (3. táblázat). Úgy tűnik tehát, hogy a gömbölyüség fajunk konzervatív alaki jellemzője. Érdekes módon a leggömbölyübb $(1,02)$ és legjobban nyomott $(1,39)$ házforma az Apor Vilmos tér-Jagelló út-Németvölgyi út, illetve Mártonhegyi út 11/D habitatjához kötődik.

A következő 5., 6. és 7. ábrák a Bürök utcai minta élő (alapsokaság: 88) és holt (alapsokaság: 52) egyedeinek gyakorisági eloszlását hasonlítják össze, azzal a céllal, hogy az idő múlásával bekövetkező morfológiai/ökológiai változás tendenciáját megismerjük.

A szélesség $(W)$ és magasság $(H)$ esetében is azt tapasztaljuk, hogy az átlagokban meglévő kis különbségek ellenére $(0,59$ illetve $0,21 \mathrm{~mm})$ a holt sokaság görbéihez viszonyítva az élő sokaság görbéi a kisebb értékek felé tolódnak el. A szélesség (W) és magasság $(\mathrm{H})$ esetében, az 1. és 2. táblázat segítségével elvégzett F-próba /szignifikanciavizsgálat (SvÁB 1981) azt mutatja, hogy a különbség $10 \%$ szinten szignifikáns.

$$
\begin{gathered}
\mathrm{F}_{\mathrm{W}}=\frac{\mathrm{s}^{2} \text { holt }}{\mathrm{s}^{2} \text { élö }}=\frac{6,0147}{3,2479}=1,8518\left(\mathrm{~s}=\text { szórás, } \mathrm{F}_{5 \%}=1,55\right) \\
\mathrm{F}_{\mathrm{H}}=\frac{\mathrm{s}^{2} \text { élő }}{\mathrm{s}^{2} \text { holt }}=\frac{4,1603}{3,8145}=1,0906\left(\mathrm{~s}=\text { szórás, } \mathrm{F}_{5 \%}=1,51\right)
\end{gathered}
$$

Mindezekből arra következtethetünk, hogy az 2019-ben gyűjtött élő egyedek a tolerancia spektrumukban - a korábbi időszak egyedeihez képest - a pesszimum irányába tolódtak el.

Míg az élő példányokon mért paraméterek értékei a holtakéhoz képest csökkentek, addig házaik nyomottabbá váltak, hiszen a gömbölyüségük $(\mathrm{W} / \mathrm{H})$ kis mértékben (7. ábra - átlag 1,19 $\rightarrow 1,20)$ növekedett.

Befejezésképpen az 1., a 2. és a 3. táblázatban közölt holt egyedek magasság és szélesség átlagértékeit ábrázoltuk a tengerszint feletti magasság függvényében (8. ábra). A szélesség és a magasság átlagainak tengerszint feletti magasságtól, áttételesen hőmérséklettől való függését bemutató 8 . ábra a következő eredmények levonását teszi lehetővé: Mindkét esetben az átlagok hasonlóan emelkedő, paralel futást mutatnak, ami arra utalhat, hogy a hőmérséklet csökkenésével nő a vizsgált héjjellemzők nagysága. A növekedés a Bürök utcáig viszonylag nagyobb, azt követően már alig változik. A Bürök utcai minta kissé nagyobb értékével 
némileg kiugrik, ami arra utalhat, hogy a hegyvidéki minták közül a „leghegyvidékibb”, azaz a mikroterében feltehetőleg legalacsonyabb a hőmérséklet. Ha a Bürök utcai gyűjtőhely leírását és a táblázatokban található adatokat összevetjük a többi gyűjtőhelyével, akkor a következőket állapíthatjuk meg: 1. Itt legnagyobb az abundancia. 2. Itt találtuk a legtöbb élő egyedet. 3 . $A \sim 50 \mathrm{~m}^{2}$ kiterjedésű élőhelyre két oldalról betonkerítés és jól záró idős fák, a rézsủ alján pedig egy magas épülettömb vet árnyékot. Tehát a többi biotóptól eltérő ökológiai faktorokkal magyarázhatjuk az itteni átlagok kiugró voltát. Természetesen nem zárhatjuk ki, hogy a különbségeket a csigaegyüttesünk genetikai állományában megmutatkozó különbség generálták. Summa summarum az ökológiai vagy a genetikai tényezők okozzák a héjalaktani különbségeket kérdésre természetesen molekuláris taxonómiai, filogenetikai vizsgálatok tudnának megbízható választ adni.

\section{Hibridizáció kérdése}

Csupán egy alkalommal (2019. 05. 21. reggel 7 óra, $12{ }^{\circ} \mathrm{C}$ ), a Bürök utca 41 . sz. elötti járdán figyeltük meg a Helix pomatia és Helix lucorum sikeres/sikertelen kopulálását. A mérések során kézbe vett $313 \mathrm{db}$ héjon a megszokottól eltérő mintázattal nem találkoztunk.

Itt szeretnénk megjegyezni, hogy a bokros biotóp szukcessziójában talált 88 E1/E2 létállapotú adult Helix lucorum mellett csupán 8 hasonló létállapotú Helix pomatia került elő!

\section{Összefoglalás}

Az abundancia meghatározására alkalmas Bürök utcai gyüjtőhelyen az adult példányok esetében 1,7 $\mathrm{db} / \mathrm{m}^{2}$, az összes élö példány esetében pedig 2,4 db/ $\mathrm{m}^{2}$ gyakorisági érték adódott. E biotópból kiinduló migráció távolsága - megfelelő ökológiai viszonyok között - naponta 10 m-es nagyságrendet is elérhetett.
Egy esetben sikerült a Helix pomatia és a Helix lucorum kopulációját megfigyelni. 313 egyed vizsgálata során korábbi hibridizációra utaló jeleket a héjmintázatban nem észleltünk.

A biometriai vizsgálatokhoz felhasznált egyedek száma a vizsgált terület adottságainak megfelelően igen különböző volt: $14,33,88,52,17,59,50$. Természetesen a nagyobb példányszámok esetében tapasztaltuk a biológiában szokásos normális eloszláshoz való közelítést.

A legkisebb szélesség látmérő (W) és magasság $(H)$ adatok nagysága: 31,7 és 26,9 mm. Ezeket az értékeket a XI. kerületi Bocskai és Daróci utcai nyitott, nagy aszfaltfelület közelében fekvő habitátjában nyertük. A legnagyobb W és H értékek: 50,6 és 41,1 mm. Ezek az értékek a Bürök utcai és az Apor Vilmos tér-Jagelló út -Németvölgyi úti gyüjtőhelyhez kötődnek. Az ökológiai szempontból igen mozaikos Apor Vilmos tér-Jagelló út-Németvölgyi úti gyűjtőterület - a kisebb méretek gyakorisága tekintetében - az árnyékosabb Bürök utcai és Mártonhegyi úti biotópok között átmenetet képez.

A különböző gyüjtőhelyek megegyeztek abban, hogy azonos osztályközben érték el "gömbölyüségük" (W/H) maximumát $(1,15-1,20)$. A ház szélességének/átmérőjének növekedésével a ház lapultabbá válását tapasztaltuk.

Azonos biotópban (Bürök utca 24-26.) végzett holt és élő példányok összehasonlító statisztikai vizsgálata során megállapítottuk, hogy az élő egyedek héjmorfológiai paraméterei $(\mathrm{W}, \mathrm{H})$ az adaptáció során szignifikánsan kisebbek, mint a korábbi népességé. További vizsgálatok szükségesek ahhoz, hogy a tapasztalt tendencia okát tisztázzuk.

A tengerszint feletti magasság növekedésével/hőmérséklet csökkenésével telítési görbének megfelelően nő az alaki jellemzők közül a szélesség és magasság átlaga, a „gömbölyúség” viszont praktice változatlan marad.

\section{Köszönetnyilvánítás}

Köszönet illeti Nacsa Kálmán barátunkat a kézirat átnézéséért és számos megjegyzéséért. 
Helix lucorum D

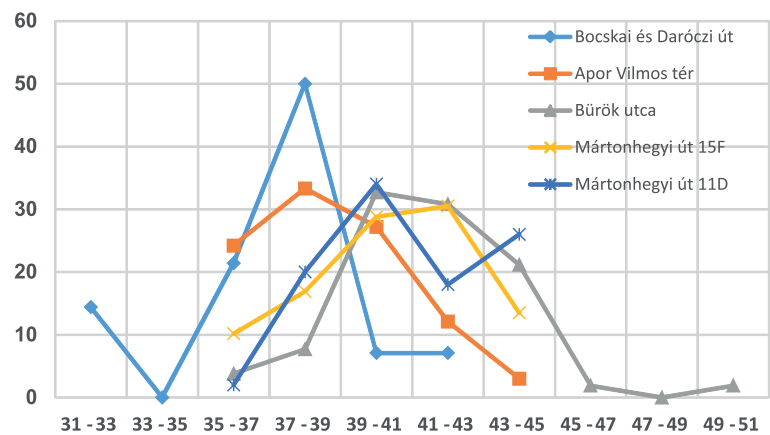

2. ábra. Holt Helix lucorum házak szélesség (W) értékeinek eloszlása a különböző gyüjtőhelyeken.

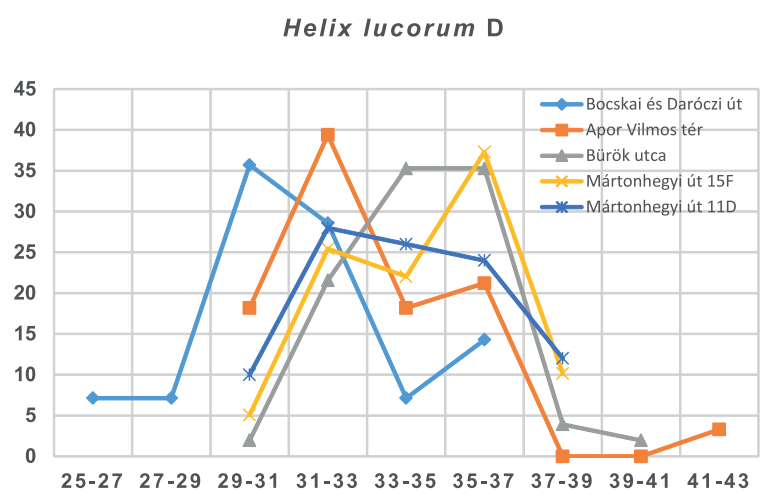

3. ábra. Holt Helix lucorum házak magasság $(H)$ értékeinek eloszlása a különböző gyüjtöhelyeken.
Helix Iucorum D

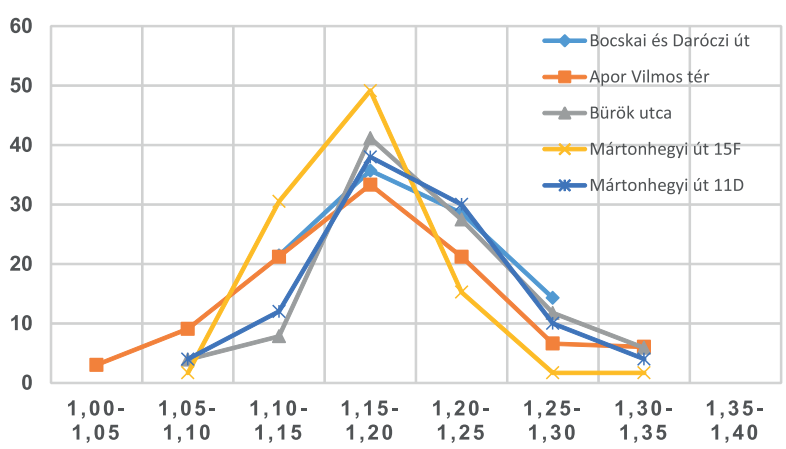

4. ábra. Holt Helix lucorum házak „gömbölyüség”

(W/H) értékeinek eloszlása a különböző gyüjtöhelyeken.

Helix lucorum Bürök utca

L (living: $88-40,81) \& D($ dead:52-41,40)

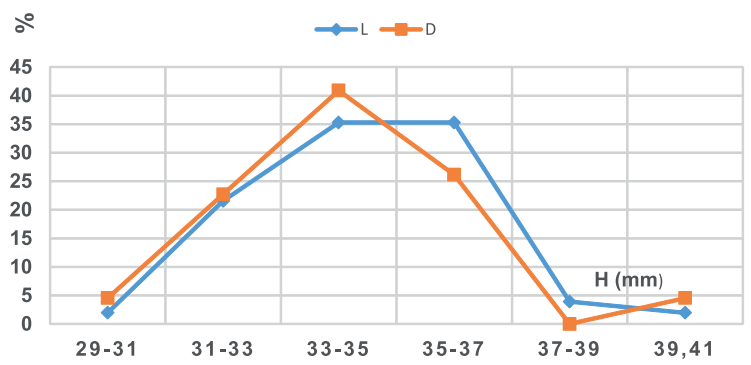

6. ábra. A Bürök utcai gyüjtöhely holt (D) és élö $(L)$ Helix lucorum házainak magasság $(H)$ eloszlása, zárójelben a példányszám, mellette az átlag található.
Helix lucorum

Bürök utca

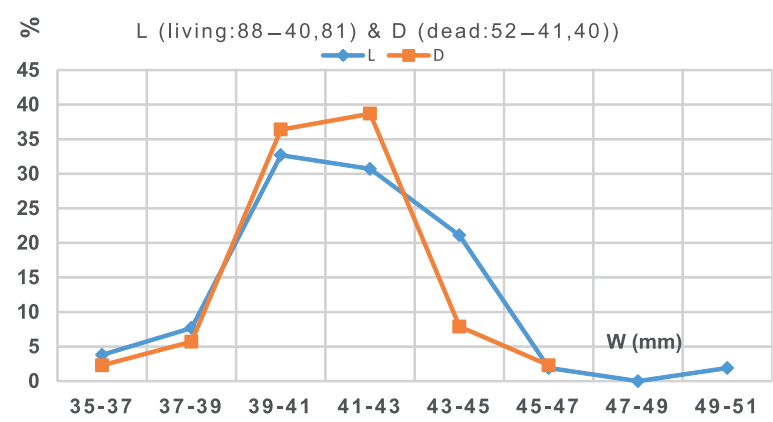

5. ábra. A Bürök utcai gyüjtőhely holt (D) és élö $(L)$

Helix lucorum házainak szélesség (W) eloszlása, zárójelben a példányszám, mellette az átlag található.

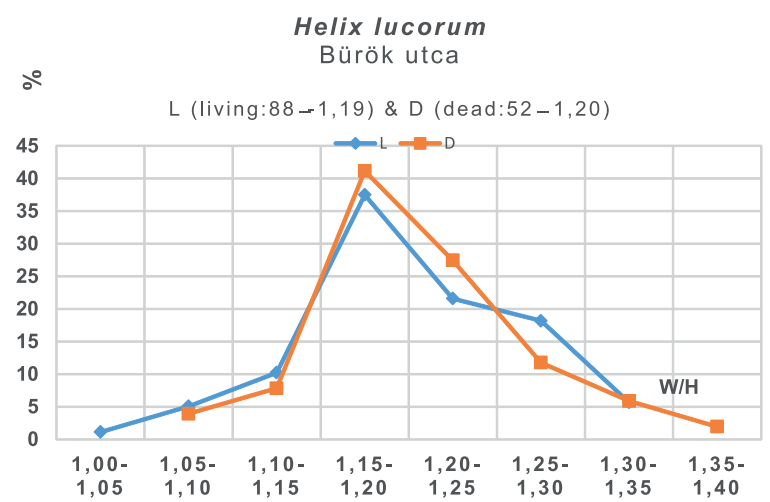

7. ábra. A Bürök utcai gyüjtőhely holt (D) és élö (L) Helix lucorum házainak „gömbölyüség” (W/H) eloszlása, zárójelben az átlag található. 


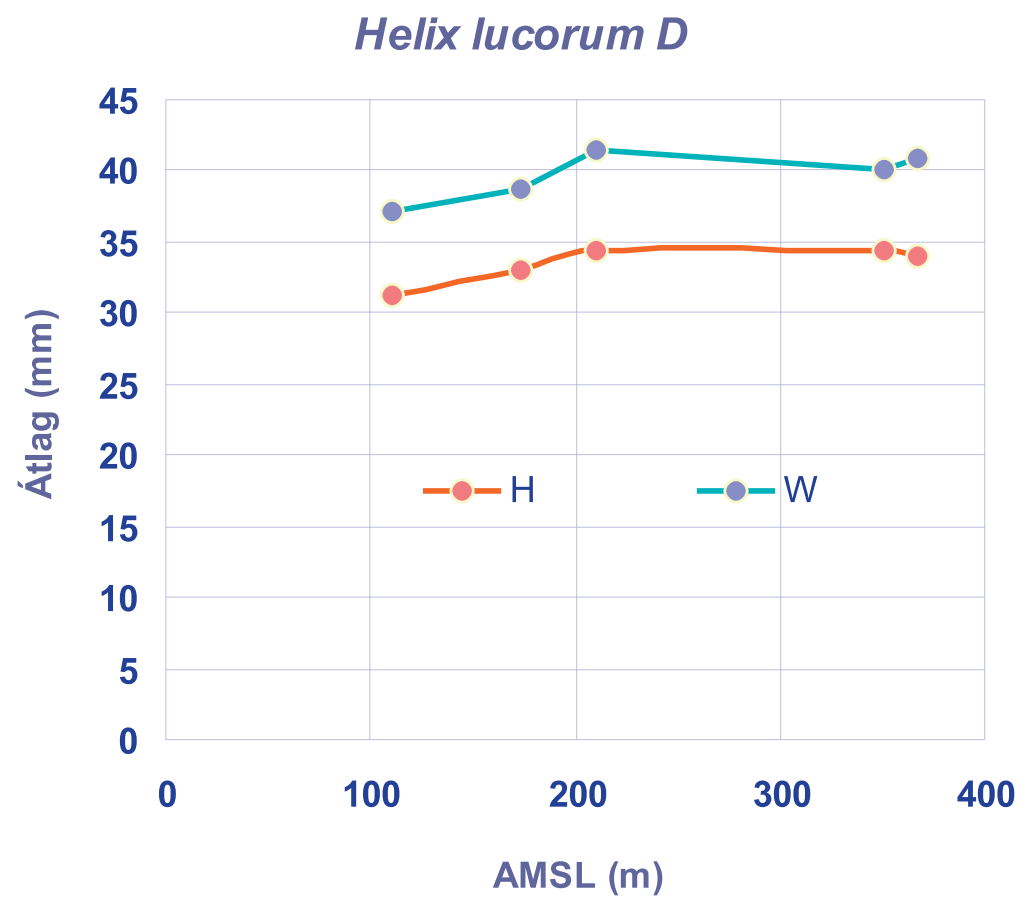

8. ábra. Holt Helix lucorum házak szélesség (W) és magasság (H) átlagainak függése a tengerszint feletti magasságtól/AMSL.

\section{Irodalom}

BoDoR, J. 2014: Kétféle éticsiga károsít. - Kertészet és Szőlészet, 34. sz. 24. o.

Dомокоs, T. 1995: A Gastropodák létállapotáról, a létállapotok osztályozása a fenomenológia szintjén. - Malakológiai Tájékoztató, 14: 79-82.

Domokos, T. 2005: Helix lucorum (Linnaeus, 1758) újabb magyarországi előfordulása. - Natura Bekesiensis, 7: 86.

Dомокоs, T. 2014: Szórványadatok Budapest belterületének - különös tekintettel a temetőkre - szárazföldi malakofaunájához (2010-2012) - Folia Historico-Naturalia Musei Matraensis, 38: 9-22.

Páll-Gergely, B., Majoros, G., Domokos, T., Juhász, A., Turóci, Á., Badacsonyı, L., Fekete, J., Asami, T. 2019: Realtime Social Networking Service rapidly reveals distributions of nonindigenous land snails in a European capital - Biolnvasions Records, 8 (4): 782-792.

SVÁB, J. 1981: Biometriai módszerek a kutatásban. Mezőgazdasági Kiadó. Budapest.
VARGA, A. 1995: Helix lucorum Linné, 1758 magyarországi betelepítése. - Malakológiai Tájékoztató, 14: 21-22.

VARGA, A. KIRÁLY, G. \& SULYOK, K. M. 2010: A Cornu aspersum O.F. Müller, 1774) és a Helix lucorum Linnaeus, 1758 adventív csigafajok hazai előfordulásának aktualizálása. - Malakológiai Tájékoztató, 28: 85-90.

Welter-Schultes, F. 2012: European non-marine molluscs, a guide for species identification. Planet Poster Editions. Göttingen. 613.

További források

https://www.daftlogic.com/sandbox-google-maps-find-altitude.htm (2020. 04. 21.)

https://hu.wikipedia.org/wiki/Feh\%C3\%A9rs\%C3\%A1vos_\%C3\%A9ti csiga (2020. 04. 21.)

http://www.molluscs.at/gastropoda/terrestrial/helix.html?/gastropoda/ terrestrial/helix/lucorum.html (2020.04.21.)

https://web.archive.org/web/20070706133831/http://www.met.hu/ omsz.php?almenu_id $=$ misc $\&$ pid $=$ metsuli $\& \mathrm{mpx}=0 \&$ pri $=1 \& \mathrm{sm} 0=$ $\& d t i=3 \& t f i=0(2020.04 .21$. 